\title{
Synthesis, Anticancer and Molecular Docking Studies of N-(1H-benzimidazol-2-yl-carbamothioyl)benzamide Analogues
}

Priyanka P. Rode*, Akshay R. Yadav, Ankita V. Chitruk, Dr. Shrinivas K. Mohite, Dr. Chandrakant S. Magdum Department of Pharmaceutical Chemistry, Rajarambapu College of Pharmacy, Kasegaon, Maharashtra, India-415404 Corresponding author E-mail:- rodepriyanka4@gmail.com, akshayyadav24197@gmail.com

\section{Article Info}

Volume 7, Issue 4

Page Number: 204-212

Publication Issue :

July-August-2020

\section{Article History}

Accepted : 10 Aug 2020

Published : 16 Aug 2020

\section{ABSTRACT}

A series of novel $\mathrm{N}$-(1H-benzimidazole-2-yl-carbamothioyl)benzamide derivatives were synthesized under microwave irradiation and evaluated for anticancer activity. The synthesized compounds were characterized by IR, NMR and mass spectral data. Complexity associated with cancer disease and prevalence of diversified cell populations indicates highly specific treatment options for treatment of cancer. Resistance to these anticancer agents has posed a great hindrance in successful treatment of cancer. Pondering this ongoing situation, it was speculated to develop novel compounds targeting cancer. All the newly synthesized compounds were further evaluated for anticancer activity against MCF-7 cell lines using MTT assay. Molecular docking studies were performed using VLifeMDS software. The compound code $3 \mathrm{c}$ exhibited good docking scores of -60.37 . The anticancer and docking results highlight the fact that the synthesized compound code $3 \mathrm{c}$ could be considered as possible hit as therapeutic agents. A significant correlation was observed between the in-silico and the in-vitro studies.

Keywords : Benzimidazole, Molecular docking, MTT assay, Anticancer activity.

\section{INTRODUCTION}

As per the present global scenario, thousands of new heterocyclic compounds either isolated from natural sources or synthesized in the laboratories are added to the literature every year. Many of these compounds have drawn the attention of researchers based on their biological, therapeutic and industrial potential ${ }^{1}$. Benzimidazoles are found to be useful intermediates 
for the development of new molecules of biological or pharmaceutical interest. Substituted benzimidazole derivatives have been found to possess biological activities such as antitumor, antimicrobial, anthelmintic, antibacterial, analgesic and antiinflammatory activity etc ${ }^{2}$. Benzimidazoles exhibit important applications such as possible Swish muscle fiber propagation inhibitors, antincancer agents, as a treatment for urinary infection and in various areas of chemistry. The organic compounds specifically with $\mathrm{N}$-heterocyclic ring systems exhibit a wide range of biological activities through effective binding to enzyme receptor site. These structures are frequently called special because of their wide repeat in bioactive mixes. In spite of incredible enthusiasm for benzimidazole ligands and basic science, the principle intrigue is in their organic exercises ${ }^{3-4}$. Breast cancer is the leading cause of death in worldwide, and the most common cancer among women. Cancer is an major prevalence. Cancer is considered one of the leading causes of disease-related mortality and the estimated cancer death rate alone will hit about 10 million by the end of $2020^{5}$. There are over 60 different organs in the body that can develop cancer from nearly any cell type in the body ${ }^{6}$. Cancer cell are formed when normal cell lose the normal regulatory mechanism controlling development and multiplication. If the cancer is present in specific area, it is said that it is benign and if the cancer cell invade another section of the body and set up secondary tumor known as metastasis 7 . Green chemistry is defined as the synthesis, design, development and application of chemical products to reduces hazardous substances. The application of green chemistry principles and practices renders regulation, control, clean-up, and remediation of the environment. The promotion of microwave assisted reactions in organic chemistry has improved the speed, reduced cost, reduced energy spent making it a sustainable process and is widely reffered as "green chemistry" measures whose applications are promoted today to minimize the use of non-renewable resources as well as polluting solvent, to reduce generation of secondary products which are often toxic and to reduce the emission of harmful gases ${ }^{8}$. Microwave assisted reactions in organic chemistry achieve the same by ensuring facilitation of faster reactions under bulk conditions as well as promoting reduction of reaction time. Reactions play the most fundamental role in synthesis. The ideology of green chemistry calls for the development of new chemical reactivities and reaction conditions that can potentially provide benefits for chemical synthesis in terms of resource and energy efficiency, product selectivity, operational simplicity, and health and environmental safety ${ }^{9-10}$. Microwave heating produces heat in entire material in the same rate and the same time at a high speed and at a high rate of reaction. Microwave assisted synthesis has become an important tool to the medicinal chemist for rapid organic synthesis. Recrystallization can affect physical and chemical stability, apparent solubility, dissolution, bioavailability and bioequivalence and drug product manufacturability, which require special attention during product development as it affects drug product quality, protection and effectiveness. Its isolation of impurities by recrystallization traditional techniques i.e crystallization of drug substance is used. It is one of the effective element in drug development ${ }^{11-12}$. The need for different organic compound libraries for drug discovery, biomaterial development, automated library screening, proteomics etc, has supported emergence of innovative technologies for rapid combinatorial organic synthesis using MAOS synthesis. Given the rapid pace of scientific research and clinical data produced by the large number of people quickly infected with SARS-CoV-2, clinicians need reliable proof of successful medical care for this infection as in this pandemic in-silico docking studies of benzimidazole have shown good results. 
Molecular docking is an attractive scaffold to understand drug biomolecular interactions for the rational drug design and discovery, as well as in the mechanistic study by placing a molecule (ligand) into the preferred binding site of the target specific region of the DNA/protein (receptor) mainly in a noncovalent fashion to form a stable complex of potential efficacy and more specificity. The information obtained from the docking technique can be used to suggest the binding energy, free energy and stability of complexes. At present, docking technique is utilized to predict the tentative binding parameters of ligand-receptor complex. In the current study insilico molecular docking was studied by VLifeMDS software were used to identify which docking method works better with the target proteins. Here we present synthesis, characterization and anticancer briefly from the docking and screening experiments ${ }^{13-}$ 26.

\section{MATERIALS AND METHODS}

All chemicals and solvents were procured from commercial sources, purified and dried using standard procedures from literature whenever required the regents were purchased from S.D fine, Research laboratory and merck laboratory, Mumbai. The melting points of synthesized compound were determined by open capillary tube method and are uncorrected. Thin layer chromatography was used confirmation of reaction and the purity of the intermediate and the final compounds by applying a single spot on TLC plate (silica gel G) using various solvents such as butane, chloroform and water system. TLC plates were visualized under iodine chamber. IR spectra were recorded on FTIR, NMR spectra were performed in DMSO solution using Bruker $300 \mathrm{MHz}$ and their chemical shift are reported in $\delta$ unit with respect to TMS as internal standard. Mass spectra were recorded on Pe sciex (model no. API 2000) software analyst 1.4.2 mode: Q1MS Q1/AUTO INJECTION from diya lab, airoli, Mumbai.

General method for the Synthesis of 2aminobenzimidazole (1a)

Mixture of o-Phenylenediamine $1.5 \mathrm{~g}$, methanol 10 $\mathrm{ml}$ and cyanogen bromide $1 \mathrm{~g}$ was irradiated for 15 min at 340 watt under microwave.

General method for the Synthesis of substituted aroyl isothiocyanate (2a-f)

A solution of substituted benzoyl chloride $(5 \mathrm{mmol})$ in acetone $(25 \mathrm{ml})$ was added dropwise to ammonium thiocyanate $(5 \mathrm{mmol})$ in acetone $(15 \mathrm{ml})$. The reaction mixture irradiated for $10 \mathrm{~min}$ at 340 watt under microwave. The reaction mixture was cooled at room temperature and the precipitate $\left(\mathrm{NH}_{4} \mathrm{Cl}\right)$ was filtered off. Solution of aroyl isothiocyanate derivatives was prepared.

General method for the synthesis of substituted N(1 $H$-benzimidazole-2-yl-carbamothioyl)benzamide derivatives (3a-f)

A product of of 2 -aminobenzimidazole $(5 \mathrm{mmol})$ was added in aroyl isothiocyanate and the reaction mixture irradiated for $10-15 \mathrm{~min}$ at 340 watt. The reaction was monitored by TLC using butane: chloroform: water (7:2:1) as mobile phase. The solid product was washed with water and recrystallised with methanol.

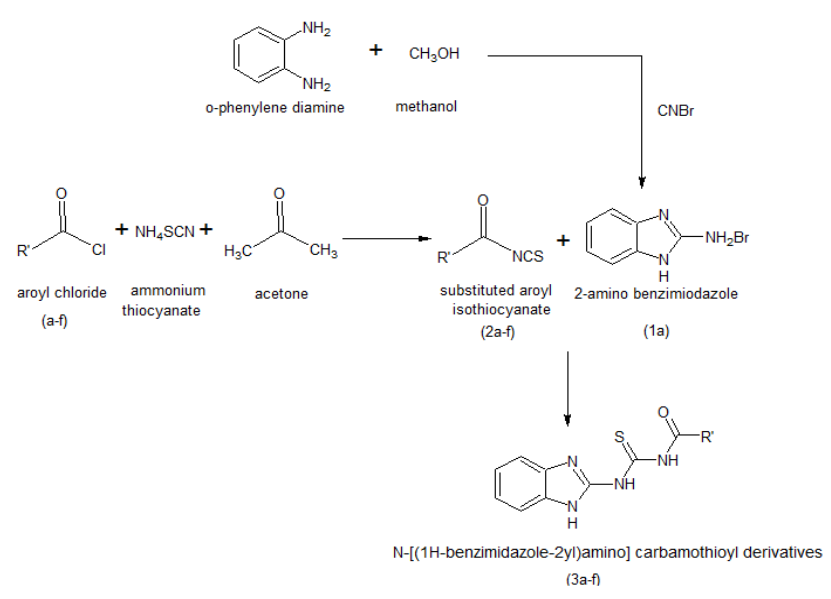

Scheme 1: Synthetic route for the preparation of the title compound (3a-f) 
Where, $\mathrm{R}^{\prime}=$

(l)

Analytical Data of Novel N-(1 $H$-benzimidazole-2-ylcarbamothioyl) benzamide derivatives:

3a. $N$-(1H-benzimidazol-2-ylcarbamothioyl) benzamide

Yield 89\%; m.p 152-154 ${ }^{\circ} \mathrm{C}$; IR (KBr, $\left.\mathrm{cm}^{-1}\right) 1154.16$ $(\mathrm{C}=\mathrm{S}), 1718.32(\mathrm{C}=0), 3468.11(\mathrm{C}-\mathrm{NH}), 1 \mathrm{H}$ NMR (DMSO, 300MHz, ppm): $\delta 7.20$ (s, 1H), 7.54-7.59 (q, $4 \mathrm{H}, \mathrm{ArH}), 7.79-7.85$ (q, $4 \mathrm{H}, \mathrm{ArH}), 8.92(\mathrm{~s}, 1 \mathrm{NH})$; mass $\mathrm{m} / \mathrm{z}(\mathrm{M}+) 296.3$.

3b. $\mathrm{N}$-(1H-benzimidazol-2-ylcarbamothioyl)-2-chloro benzamide

Yield 81\%; m.p 168-170 ${ }^{\circ} \mathrm{C}$; IR (KBr, $\left.\mathrm{cm}^{-1}\right) 1182.16$ $(\mathrm{C}=\mathrm{S}), 1711.84(\mathrm{C}=0), 3412.12(\mathrm{C}-\mathrm{NH}), 3489.24,(\mathrm{C}-\mathrm{Cl})$, 1H NMR (DMSO, 300MHz, ppm): $\delta 7.39$ (s, 1H), 7.58-7.66 (q, 4H, ArH), 7.72-7.81 (q, 4H, ArH), 8.84 (s, 1NH); mass m/z (M+) 330.7.

3c. $N$-(1H-benzimidazol-2-ylcarbamothioyl)-4-chloro benzamide

Yield 77\%; m.p 155-157 ${ }^{\circ} \mathrm{C}$; IR (KBr, $\left.\mathrm{cm}^{-1}\right) 1151.28$ $(\mathrm{C}=\mathrm{S}), \quad 1716.62 \quad(\mathrm{C}=0), \quad 3410.29 \quad(\mathrm{C}-\mathrm{Cl}), \quad 3468.20$ (C-NH), 1H NMR (DMSO, 300MHz, ppm): $\delta 7.25$ (s,
$1 \mathrm{H})$, 7.69-7.78 (d, 2H, ArH), 7.85-7.90 (q, 4H, ArH), $8.90(\mathrm{~s}, 1 \mathrm{NH}) ;$ mass m/z $(\mathrm{M}+) 330.7$.

\section{3d. $N$-(1H-benzimidazol-2-ylcarbamothioyl)-2,4-} dichloro benzamide

Yield 75\%; m.p $150-152^{\circ} \mathrm{C}$; IR (KBr, cm- $\left.{ }^{-1}\right) 1159.12$ $(\mathrm{C}=\mathrm{S}), 1711.41,(\mathrm{C}=0), 3471.42,(\mathrm{C}-\mathrm{Cl}), 3479.19$, (CNH), 1H NMR (DMSO, 300MHz, ppm): $\delta 7.25$ (s, 1H), 7.51-7.59 (q, 4H, ArH), 7.81-7.90 (t, 3H, ArH), 8.98 (s, $1 \mathrm{NH})$; mass $\mathrm{m} / \mathrm{z}(\mathrm{M}+) 365.2$.

\section{3e. $N$-(1H-benzimidazol-2-ylcarbamothioyl)-4-} methoxy benzamide

Yield 83\%; m.p $148-150^{\circ} \mathrm{C}$; IR $\left(\mathrm{KBr}, \mathrm{cm}^{-1}\right) 1152.29$ $(\mathrm{C}=\mathrm{S}), 1734.10(\mathrm{C}=0), 2850.18\left(\mathrm{O}-\mathrm{CH}_{3}\right), 3441.20$ (C$\mathrm{NH}), 1 \mathrm{H}$ NMR (DMSO, 300MHz, ppm): $\delta 1.098$ (d, 2H, Ar-OCH3), 7.21 (s, 1H), 7.29-7.34 (t, 3H, ArH), 7.84-7.92 (q, 4H, ArH), $8.75(\mathrm{~s}, 1 \mathrm{NH}) ;$ mass m/z (M+) 326.3.

\section{3f. $N$-(1H-benzimidazol-2-ylcarbamothioyl)-4-fluoro} benzamide

Yield 94\%; m.p 135-1370 C; IR (KBr, $\left.\mathrm{cm}^{-1}\right) 1156.32$ $(\mathrm{C}=\mathrm{S})$, 1337.20, (C-F), $1719.54(\mathrm{C}=0), 3481.45(\mathrm{C}-\mathrm{NH})$, 1H NMR (DMSO, 300MHz, ppm): $\delta 7.13(\mathrm{~s}, 1 \mathrm{H})$, 7.20-7.37 (q, 4H, Ar-F), 7.94-7.98 (t, 3H, ArH), 8.53 (s, $1 \mathrm{NH}) ;$ mass $\mathrm{m} / \mathrm{z}\left(\mathrm{M}^{+}\right) 314.5$.

\section{ANTICANCER ACTIVITY:}

\section{MTT assay and Anti-proliferative activity}

The in-vitro anti-proliferative activity was carried out on human carcinoma cell line namely MCF-7. Cell lines were grown in DMEM-HG supplemented with $10 \%$ heat-inactivated FBS, $2 \%$ penicillinstreptomycin and $2.5 \mu \mathrm{g} / \mathrm{mL}$ amphotericin-B solutions. Cell lines were incubated at $37^{\circ} \mathrm{C}$ in a humidified atmosphere of $95 \%$ air, 5\% CO2. Following 24-48 hrs. of incubation period. 
Adherent cells were detached using Trypsin-EDTA solution. Cell count was determined using the Luna automated cell counter based on trypan blue dye exclusion method. Cytotoxicity of the novel $\mathrm{N}-(1 \mathrm{H}-$ benzimidazole-2-yl-carbamothioyl)benzamide derivatives have been determined using MTT 3-(4,5dimethylthiazol-2-yl)-2,5-diphenyltetrazolium bromide) assay.

\section{Cell Viability Assay (MTT Assay)}

$200 \mu \mathrm{L}$ cell suspension was seeded in 96-well microplates at a density of 25,000 cells/well and incubated for $24 \mathrm{hrs}$, all cells were seeded in duplicates with test compounds having range of concentrations from $50 \mu \mathrm{M}-500 \mu \mathrm{M}$, incubated in a $\mathrm{CO}_{2}$ incubator at $37^{\circ} \mathrm{C}$. Treated cells were thereafter incubated with 10 $\%$ MTT $(5 \mathrm{mg} / \mathrm{ml})$ for $3 \mathrm{hrs}$. The culture medium was then aspirated and 200 $\mu \mathrm{L}$ dimethyl sulfoxide (DMSO; Sigma-Aldrich, India) was added. 5-Fluorouracil (5FU) was used as standard. Cell viability was determined by measuring the absorbance on a microplate reader at $570 \mathrm{~nm}$. Cell viability was calculated as a percentage of viable cells at different test concentrations relative to the control (5-FU) cells $[\%$ cell viability $=(\mathrm{A} 570$ of treated cells $/ \mathrm{A} 570$ of control cells) $\times 100 \%]^{27-28}$.

\section{MOLECULAR DOCKING STUDY:}

The docking study was performed using the VLife MDS on six N-[(1H-benzimidazole-2yl)amino] carbamothioyl derivatives. VLifeMDS provided both rigid (no torsional flexibility for a protein as well as a ligand) and flexible (torsional flexibility to a ligand with a rigid protein) docking of the molecules. The target or receptor was either experimentally known or theoretically generated through knowledge-based protein modeling. The molecular docking tool has been developed to get a preferred geometry of interaction of ligand-receptor complexes having minimum interaction energy supported different scoring functions viz. only electrostatics, the sum of steric and electrostatic (parameters from the force field), and the dock score. This utility allowed us to screen a set of compounds for lead optimization. VLife MDS uses the genetic algorithm, Piecewise Linear Pairwise Potential (PLP) and Grid algorithms to minimize the interaction energy between the ligand and receptor protein.

\section{Selection of receptor}

The crystal structure potent inhibitors of NUDT5 silence hormone signaling in breast (PDB Code-5NQR) was downloaded from protein data bank and water molecules in the crystal structure were deleted. The optimized receptor was then saved as mol file and used for docking simulation.

\section{Ligand preparation}

The 2D structures of the compounds were built and then converted into the 3D. The 3D structures were then energetically minimized up to the rms gradient of 0.01 using MMFF.

\section{Identification of cavities}

By using cavity determination option of software, cavities of enzyme were determined. The cavities in the receptor were mapped to assign an appropriate active site. The basic feature used to map the cavities were the surface mapping of the receptor and identifying the geometric voids as well as scaling the void for its hydrophobic characteristics. Hence, all the cavities that are present in receptor are identifed and ranked based on their size and hydrophobic surface area considering the dimensions and hydrophobic surface area, cavity was found to be the best void as an active site.

\section{Scoring Function}

Distinction of good or bad docked conformation is based on scoring or fitness function. MDS uses fitness functions on only electrostatic and both steric and electrostatic interactions between receptor ligand as 
well as dock score scoring function. The dock score compute binding affinity of a given protein-ligand complex with known 3D structure ${ }^{29-32}$.

\section{RESUTLS AND DISCUSSION}

\section{Chemistry}

In first step o-phenylenediamine, methanol and cyanogen bromide was irradiated for $15 \mathrm{~min}$ at 340 watt under microwave. In the subsequent step a solution of substituted benzoyl chloride in was added dropwise to ammonium thiocyanate in acetone. The reaction mixture irradiated for $10 \mathrm{~min}$ at 340 watt under microwave. The reaction mixture was cooled at room temperature and the precipitate $\left(\mathrm{NH}_{4} \mathrm{Cl}\right)$ was filtered off. Solution of aroyl isothiocyanate derivative was prepared (2a-f). A product of of 2aminobenzimidazole was added in aroyl isothiocyanate and the reaction mixture irradiated for 10-15 min at 340 watt. The reaction was monitored throughout by TLC using butane: chloroform: water (7:2:1) as mobile phase. The solid product was washed with water and purified by washing with methanol. The reaction sequence is shown in Scheme 1 . Microwave assisted synthesis is a convenient way toward the goal of green chemistry. Microwave irradiation can be used to in chemical synthesis as a heat source; it is very efficient and can be used to significantly reduce reaction times of numerous synthetically useful chemical transformations. Thus, microwave-assisted synthesis has advantages over conventional technology: it is more energy efficient and it can lead to improved isolated yields of products with green synthesis. The synthesized compounds were characterized by spectral analysis and all the compounds were in full harmony with the proposed structures.

\section{Anticancer activity}

The synthesized $\mathrm{N}$-(1H-benzimidazole-2-ylcarbamothioyl)benzamide derivatives (3a-f) were evaluated their cytotoxicity on MCF-7 cell lines $(50 \mu \mathrm{M}-500 \mu \mathrm{M})$ in order to obtain the effective concentration at $50 \%$ of the inhibited cells. The results are expressed as $50 \%$ of the total available cells inhibited after $72 \mathrm{hrs}$. of incubation. The compounds $3 \mathrm{c}$ showed good cytotoxicity having IC 50 of $2.5 \mu \mathrm{M}$ on MCF-7 cell lines respectively. The results of the MTT assay of these compounds were compared with the results of the standard 5-fluorouracil.

Table 1: IC 50 values of the novel of $\mathrm{N}-\left(1 H^{-}\right.$ benzimidazole-2-yl-carbamothioyl)benzamide derivatives (3a-f) for anticancer activty

\begin{tabular}{|c|c|c|}
\hline $\begin{array}{c}\text { Sr. } \\
\text { no }\end{array}$ & $\begin{array}{c}\text { Compound } \\
\text { code }\end{array}$ & $\begin{array}{c}\text { IC50 values of } \\
\text { benzimidazole in } \mu \mathrm{M}\end{array}$ \\
\cline { 2 - 3 } & MCF-7 \\
\hline 1 & $3 \mathrm{a}$ & 41.2 \\
\hline 2 & $3 \mathrm{~b}$ & 15.4 \\
\hline 3 & $3 \mathrm{c}$ & 2.5 \\
\hline 4 & $3 \mathrm{~d}$ & 68.3 \\
\hline 5 & $3 \mathrm{e}$ & 51.4 \\
\hline 6 & $3 \mathrm{f}$ & 104.8 \\
\hline 7 & 5 -fluorouracil & 7.4 \\
\hline
\end{tabular}

\section{Molecular docking studies}

The Molecular docking study were conducted with potent inhibitors of NUDT5 silence hormone signaling in breast (PDB code-5NQR) for anti-cancer activity which showed better docking scores than the reference compounds 5-fluorouracil and the results were presented in Table 2. Compound code $3 \mathrm{~b}$ and $3 \mathrm{c}$ 
showed good docking scores -59.43 and -60.37 considered as good anticancer agents because of good binding scores. Compound code $3 \mathrm{c}$ showed hydrogen bond interaction with GLN80B and aromatic interaction with ARG89B presented in Figure 1.

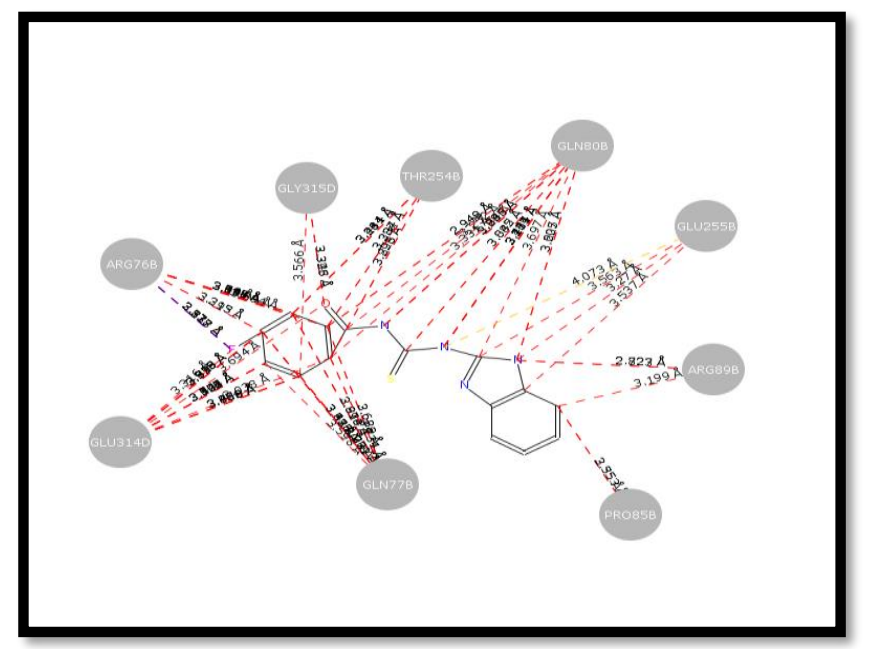

Fig 1: 2D representation of docking poses of compound code $3 \mathrm{c}$

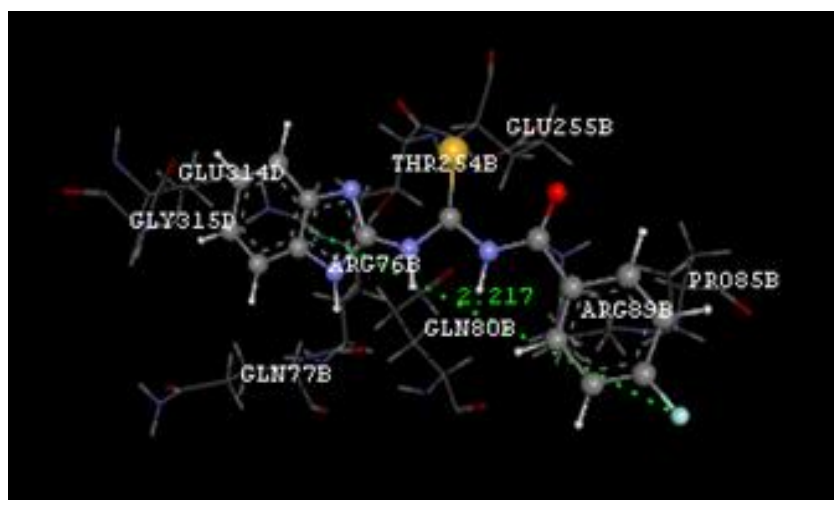

Fig 2: ligand 3c was shown in ball stick model

Table 2: Anticancer activity result of molecular docking studies by using GRIP batch docking

\begin{tabular}{|c|c|c|}
\hline Sr. no & $\begin{array}{c}\text { Compound } \\
\text { code }\end{array}$ & $\begin{array}{c}\text { Docking score } \\
(\mathrm{Kcal} / \mathrm{mol})\end{array}$ \\
\hline 1 & $3 \mathrm{a}$ & -52.01 \\
\hline 2 & $3 \mathrm{~b}$ & -59.43 \\
\hline
\end{tabular}

\begin{tabular}{|c|c|c|}
\hline 3 & $3 c$ & -60.37 \\
\hline 4 & $3 d$ & -50.08 \\
\hline 5 & $3 e$ & -57.77 \\
\hline 6 & $3 f$ & -44.06 \\
\hline 7 & 5-Fluorouracil & -62.50 \\
\hline
\end{tabular}

\section{CONCLUSION}

Series of novel substituted $\mathrm{N}-(1 H$-benzimidazole-2yl-carbamothioyl) benzamide derivatives (3a-f) was synthesized by microwave heating can dramatically shorten reaction times, increase product purities and yields, and allow precise control of reaction parameters. Thus, under microwave irradiation, the reactions are completed within less time to afford the products in good yields. Molecular docking studies further help in understanding the various interactions between the ligands and enzyme active sites in detail and thereby help to design novel potent inhibitor. The docking experiments were carried out for all the synthesized compounds and compared the docking score with reference compound 5-fluorouracil. The compounds code $3 \mathrm{~b}$ and $3 \mathrm{c}$ showed higher binding score, which are further attributed to the anticancer activity of these compound. All the synthesized subjected for anticancer activity among all, the compound code 3c had good anticancer activity. Electron withdrawing groups seemed to be necessary factors in providing higher anticancer activity.

\section{ACKNOWLEDGEMENT}

I express my sincere thanks to Vice-principal Prof. Dr. S. K. Mohite and Principal Prof. Dr. C. S. Magdum for providing me all necessary facilities. 


\section{REFERENCES}

[1]. Gullapelli K, Brahmeshwari G, Ravichander M, Kusuma U. Synthesis, antibacterial and molecular docking studies of new benzimidazole derivatives. Egypt. j. basic appl. sci. 2017; 4(4): 303-309.

[2]. Honmane P, Yadav A, Singh S, Mohite S. Microwave Assisted Synthesis of Novel Benzimidazole Derivatives as Potent Antileishmanial and Antimalarial Agents. Int. J. Curr. Adv. Res. 2020; 09(07): 22742-22746.

[3]. Rajput M. D, Yadav A. R, Mohite S. K. Synthesis, Characterization of Benzimidazole Derivatives as Potent Antimicrobial Agents. International Journal of Pharmacy \& Pharmaceutical Research. 2020; 17(4): 279-285.

[4]. Yadav A, Mohite S, Magdum C. Synthesis, Characterization and Biological Evaluation of Some Novel 1,3,4-Oxadiazole Derivatives as Potential Anticancer Agents. Int. j. sci. res. sci. technol. 2020; 7(2): 275-282.

[5]. Yadav A, Mohite S. Anticancer Activity and InSilico ADMET Analysis of Malvastrum Coromandelianum. International Journal of Pharma Sciences and Research. 2020; 11(5): 7173.

[6]. Yadav A, Mohite S. Cancer- A Silent Killer: An Overview. Asian J. Pharm. Res. 2020; 10(3): 213-216.

[7]. Chitruk A, Yadav A Rode P, Mohite S, Magdum C. Synthesis and toxicological evaluation using brine shrimp lethality assay of Novel 1,2,4triazole derivatives with anticancer activity. Int. J. Curr. Adv. Res. 2020; 09(08)(A): 2287722881.

[8]. Yadav A, Mohite S. Design, Synthesis and Characterization of Some Novel benzamide derivatives and it's Pharmacological Screening. Int. j. sci. res. sci. technol. 2020; 7(2): 68-74.
[9]. Yadav A, Mohite S. A Brief Review: Microwave Chemistry and its Applications. Res. J. Pharma. Dosage Forms and Tech. 2020; 12(3): 191-197.

[10]. Chitruk A, Yadav A Rode P, Mohite S, Magdum C. Microwave assisted synthesis, antimicrobial and anti-inflammatory potential of some novel 1,2,4-triazole derivatives. Int. j. sci. res. sci. technol. 2020; 7(4): 360-367.

[11]. Yadav A, Mohite S, Magdum C. Comparative Study of Conventional and Microwave Assisted Synthesis of some Organic Reactions. Asian J. Pharm. Res. 2020; 10(3): 217-220.

[12]. Yadav A, Mohite S. Different Techniques and Characterization of Polymorphism with their Evaluation: A Review. Asian J. Pharm. Tech. 2020; 10(3): 213-216.

[13]. Rode P, Yadav A, Chitruk A, Mohite S, Magdum C. Microwave assisted synthesis, toxicological assessment using brine shrimp lethality assay and antimicrobial potential of new series of benzimidazole derivatives. Int. J. Curr. Adv. Res. 2020; 09(08)(A): 22900-22905.

[14]. Suryawanshi V, Yadav A, Birajdar R, Jagtap N, Vambhurkar G, Patil P. Optimization of ayurvedic herbal medicine by nanoformulation. Asian J. Res. Pharm. Sci. 2019; 9(1): 55-56.

[15]. Yadav A, Mohite S. Green Chemistry approach for Microwave assisted synthesis of some Traditional Reactions. Asian J. Research Chem. 2020; 13(4): 261-264.

[16]. Yadav A, Mohite S, Magdum C. Microwave assisted synthesis of some Traditional reactions: Green chemistry approach. Asian J. Research Chem. 2020; 13(4): 275-278.

[17]. Yadav A, Mohite S, Magdum C. Preparation and Evaluation of Antibacterial Herbal Mouthwash against Oral Pathogens. Asian J. Res. Pharm. Sci. 2020; 10(3): 149-152.

[18]. Yadav A, Mohite S. Screening of In-vitro antiinflammatory and Antibacterial assay of Malvastrum Coromandelianum. International 
Journal of Pharma Sciences and Research. 2020; 11(4): 68-70.

[19]. Yadav A, Mohite S. Rajput M, Suryawanshi V, Birajdar R, Patil M. Antioxidant Activity of Psidium guajava Leaf Extracts. Res. J. Pharma. Dosage Forms and Tech. 2020; 12(3): 159-161.

[20]. Yadav A, Mohite S. ADME analysis of phytochemical constituents of Psidium guajava. Asian J. Res. Chem. 2020; 13(5): 102-105.

[21]. Yadav A, Mohite S. Recent advances in protein and peptide drug delivery. Res. J. Pharma. Dosage Forms and Tech. 2020; 12(3): 205-212.

[22]. Yadav A, Mohite S. A Novel approach for treatment of COVID-19 with Convalescent Plasma. Res. J. Pharma. Dosage Forms and Tech. 2020; 12(3): 227-230.

[23]. Yadav A, Mohite S. A Review on Novel Coronavirus (COVID-19). International Journal of Pharma Sciences and Research. 2020; 11(5): 74-76.

[24]. Yadav A, Mohite S. A Review on severe acute respiratory infection (SARI) and its clinical management in suspect/confirmed novel coronavirus (nCoV) cases Res. J. Pharma. Dosage Forms and Tech. 2020; 12(3): 178-180.

[25]. Honmane P, Yadav A, Singh S, Mohite S. 3D printing technology in pharmaceuticals and biomedical. World J Pharm Pharm Sci. 2020; 9(9): 598-609.

[26]. Dar A, Mir S. Molecular Docking: Approaches, Types, Applications and Basic Challenges. J Anal Bioanal Tech. 2017; 8(2): 1-3.

[27]. Vinayak A, Sudha M, Adarsha H, Lalita K, Kumar R. Design, Synthesis and Cytotoxic evaluation of Novel 2-(4-N, N-dimethyl) pyridine containing 1,3,4-oxadiazole moiety. Asian J Biomed Pharm Sci. 2014; 04(37): 1-5.

[28]. Desai, N.C, Somani, H., Trivedi, A., Bhatt, K., Nawale, L., Khedkar, V.M., Jha, P.C., Sarkar, D., Synthesis, biological evaluation and molecular docking study of some novel indole and pyridine based 1,3,4-oxadiazole derivatives as potential antitubercular agents. Bioorg Med Chem Lett. 2016; 18(4): 1-22.

[29]. Bhosale M, Yadav A, Magdum C, Mohite S. Molecular Docking Studies, Synthesis, Toxicological Evaluation using Brine Shrimp (Artemia salina L.) Model and Antiinflammatory Activity of Some N-(substituted)5-phenyl-1,3,4-thiadiazol-2-amine Derivatives. Int J Sci Res Sci \& Technol. 2020; 7(5): 51-62.

[30]. Sanghani H, Ganatra S, Pande R. MolecularDocking Studies of Potent Anticancer Agent. Computer Sci System Biol. 2012; 5(1): 12-15.

[31]. Bhosale M, Yadav A, Magdum C, Mohite S. Synthesis, molecular docking studies and biological evaluation of 1,3,4-thiadiazole derivatives as antimicrobial agents. Int. J. Curr. Adv. Res. 2020; 09(08)(A): 22894-22899.

[32]. Sharma D, Kumar S, Narasimhan B, Ramasamy K, Lim S, Shah S, Mani V. 4-(4-bromophenyl)thiazol-2-amine derivatives: synthesis, biological activity and molecular docking study with ADME profile. BMC Chem. 2019; 13: 5260.

\section{Cite this article as :}

Priyanka P. Rode, Akshay R. Yadav, Ankita V. Chitruk, Dr. Shrinivas K. Mohite, Dr. Chandrakant S. Magdum, "Synthesis, Anticancer and Molecular Docking Studies of N-(1H-benzimidazol-2-ylcarbamothioyl)benzamide Analogues", International Journal of Scientific Research in Science and Technology (IJSRST), Online ISSN : 2395-602X, Print ISSN : 2395-6011, Volume 7 Issue 4, pp. 204-212, July-August 2020. Available at doi: https://doi.org/10.32628/IJSRST207463 Journal URL: http://ijsrst.com/IJSRST207463 